\title{
RELATION BETWEEN SOLAR ACTIVITY PARAMETERS AND EL NIÑO
}

\author{
Kirov B., Georgieva K.
}

Space Research ant Technologies Institute - BAS, Sofia, Bulgaria

\section{СВЯЗЬ МЕЖДУ ПАРАМЕТРАМИ СОЛНЕЧНОЙ АКТИВНОСТИ И ЭЛЬ НИНЬО}

\author{
Киров Б., Георгиева К. \\ Институт космических исследваний и технологий - БАН, София, Болгария
}

Долгопериодические флуктуачии климата часто связаны с крупномасштабныли изменениями в атмосферной цииркуляции, влияющими на разные и видимо несвязанные части Земли. Пример такого явления - Эль Ниньо/Южная осциллячиия (El Niño/Southern Oscillation - ENSO). Эль Ниньо/Южная осцилляиия является возмущением океанскоатмосферной системы в тропическом Тихом океане с важными последствиями для погоды и климата во всем мире. Во время событий Эль Ниньо (положительная фаза ENSO) температура морской воды в экваториальном Тихом океане становится еще выме, пассаты в иентральной и западной части Тихого океана ослаблены, интенсивные осадки передвигаются к востоку, приводя к затоплениям в Перу и к засухам в Индонезии и Австралии. Передвижение к востоку атмосферного источника тепла над самой теплой водой приводит к большим изменениям в глобальной атмосферной ииркуляции, что в свою очередь вызывает изменения погоды в регионах, весьма удаленных от тропического Тихого океана.

В настоящей работе мы сравниваем вековые вариаџии ENSO с вековыми вариациями солнечной активности и находим тесную связь между ними. Мы предполагаем, что влияние солнечной активности на это крупномасштабное явление обусловлено атмосферными центрами действия, которые подвержены изменениям интенсивности и расположения под влиянием долгосрочных вариаций солнечной активности.

DOI: 10.31725/0552-5829-2018-215-218

\section{Introduction}

During normal, non El Niño conditions (Fig. 1a) the trade winds are strong, sea level at Indonesia is about half a meter higher than at Peru. The water is colder in the east and warmer in the west. The thermocline in the west is deep $(150 \mathrm{~m})$ and shallow $(30 \mathrm{~m})$ in the east. The rising air over the warm pool in the western Pacific is associated with rainfall. In the process, heat is released.

El Niño is a disruption of the ocean-atmosphere system in the Tropical Pacific having important consequences for weather and climate around the globe. During El Niño events (Fig. 1b), sea surface temperatures in the east equatorial Pacific becomes warmer and the center of the west Pacific warm pool migrates eastwards, the trade winds relax in the central and western Pacific leading to a depression of the thermocline in the eastern Pacific, and an elevation of the 
thermocline in the west. Rainfall follows the warm water eastward, with associated flooding in Peru and drought in Indonesia and Australia.

The eastward displacement of the atmospheric heat source overlaying the warmest water results in large changes in the global atmospheric circulation, which in turn force changes in weather in regions far removed from the tropical Pacific [1].

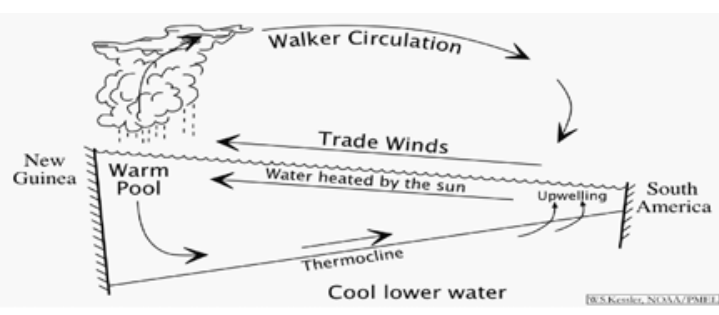

Fig. 1a.

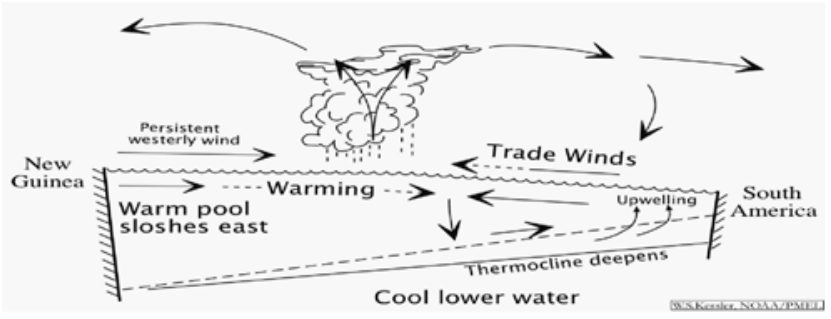

Fig. 1b.

This phenomenon influences great parts of the world and has therefore major contribution to global climate on the year-to-year time-scales. However, the fundamental mechanisms behind the variability of El Niño, especially on decadal and longer time-scales, are still unclear.

\section{Data}

To study the long-term trends of El Niño, we use the reconstruction of Quinn et al. [2] and the update of Ortlieb [3]. They based their identification upon a literature search for the occurrence over the north Peruvian coastal region and its adjacent waters of significant variations of travel times between ports along the coast of Peru, data from ship logs noting unusual sea and weather conditions, sensing unusual sea and air temperatures, etc. Quinn et al. ranged their index in six categories: from 0 - neutral or cold (La Niña) to 6 - very strong. For more recent times, we use the Cold Tongue Index (CTI) - the average SST anomalies over $6 \mathrm{~N}-6 \mathrm{~S}, 180-90 \mathrm{~W}$ [4].

The index of Quinn et al. spans back to 1525 . For this early time we have no sunspot data, so for the evaluation of solar activity we use the group sunspot data of Hoyt and Schatten beginning in 1610 [5]. For comparison of solar activity with CTI we use mean annual international sunspot numbers provided through ftp://ftp.ngdc.noaa.gov/STP/SOLAR_DATA/SUNSPOT_NUMBERS.

\section{El Niño and solar activity}

The comparison between Quinn's El Niño index and the group sunspot numbers is presented in Fig. 2. The dependence of El Niño on solar activity is with a correlation coefficient of -75.8 with $\mathrm{p}=0.000001$. For verification, in Fig.3 CTI and international sunspot numbers are presented for the period 1871- 
1998. The correlation between their 30-year climatic normals is -67.3 with $\mathrm{p}=0.02$.

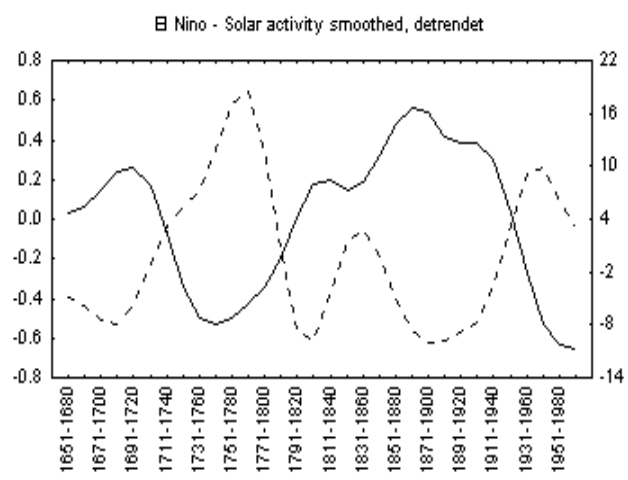

Fig. 2.

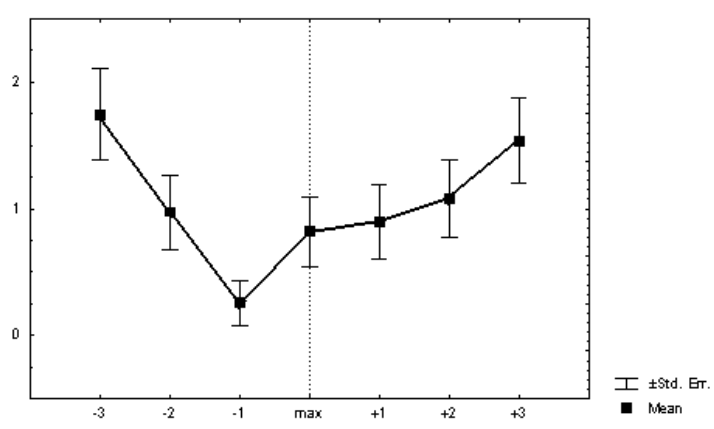

Fig. 4.

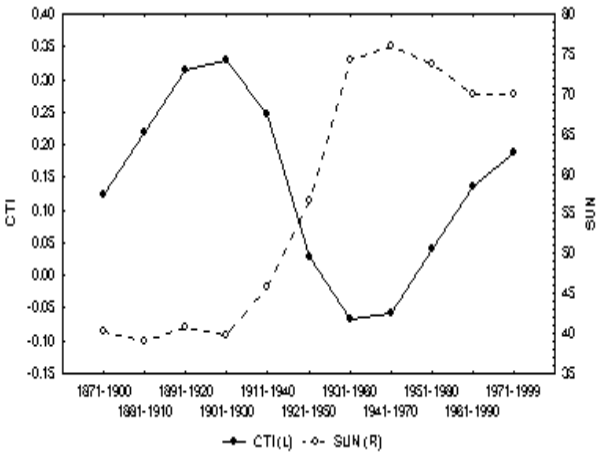

Fig. 3.

The relation between El Niño and solar activity is further demonstrated by the superposed epoch method. In this method, the average value of Quinn's index (the intensity of El Niño) is calculated in the years of solar maximum, one year before and after the maximum, two years before and afte the maximim, etc. (Fig. 4).

A clearly expressed minimum is observed one year before solar maximum. The statistical significance is evaluated with Student's t-criterion, and it better than $99 \%$ with $t=3.62$ for 74 degrees of freedom.

\section{EI Niño and the southern hemisphere centers of action}

For the Southern Hemisphere centers of action, the data set begins in 1958, so their 30-year averages cannot be directly compared to solar activity. Therefore, to study their behavior in the secular solar cycle, we have compared the values of the pressure anomalies relative to the overall mean in consecutive solar activity maxima: 1958, 1968, 1979 and 1989. The pressure in the Indian Ocean High (west of the Dateline, $77.5^{\circ} \mathrm{E}, 31.2^{\circ} \mathrm{S}$ ) is inversely related to solar activity, with $r=-0.80$ for the "winter" months (December to January) - Fig. 5, top panel. To the east of the Dateline, in the Southern Pacific High $-117^{\circ} \mathrm{W}, 31.4^{\circ} \mathrm{S}$ (Fig. 5, bottom panel), the pressure is in phase with solar activity, the highest correlation being for “autumn” (September to November): $r=0.80$. (El Nino phenomena begin in the end of the year). For this small number of data points, it is difficult to evaluate the statistical significance, however the pressure differences in both centers of action are more than twice the standard deviations (DP = $0.81 \mathrm{mb}$ with $\mathrm{r}=0.37 \mathrm{mb}$ for the Southern Pacific High, and $\mathrm{DP}=0.65 \mathrm{mb}$ with $\mathrm{r}=0.31 \mathrm{mb}$ for the Indian Ocean High). 

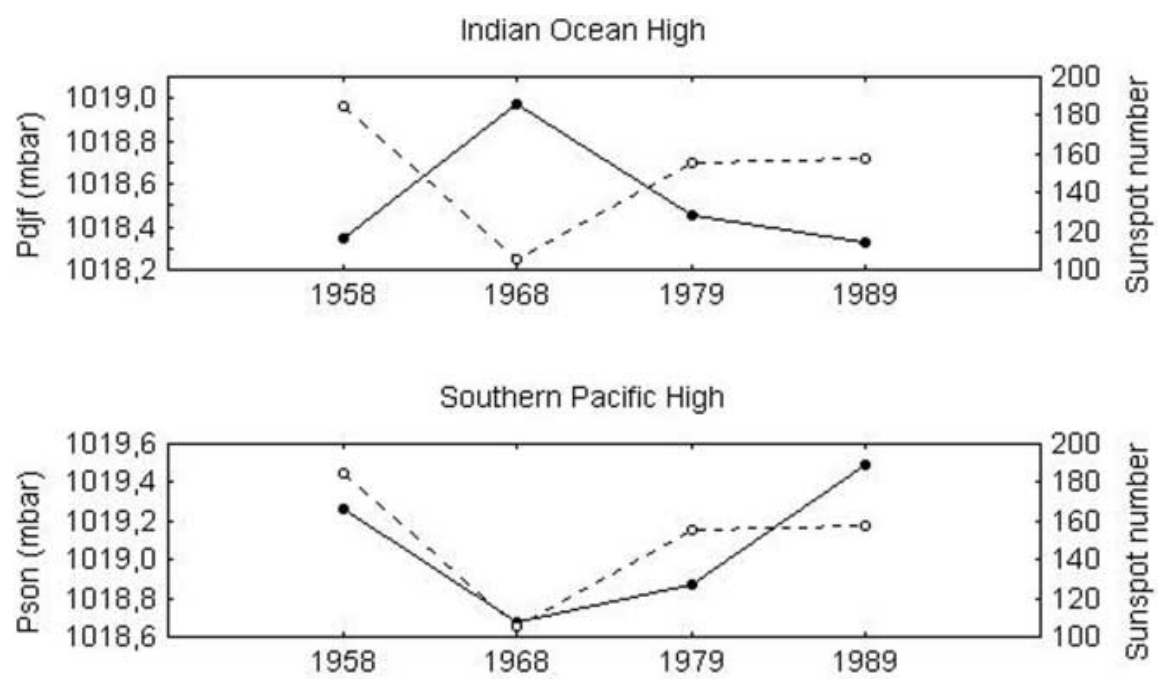

Fig. 5. Solar activity in four consecutive 11-year cycles maxima (broken line) and average pressure anomalies (solid line) from December to February - Pdjf - in the Indian Ocean High, top panel, and from September to November - Pson - in the Southern Pacific High, bottom panel.

\section{Summary}

The large-scale phenomenon orchestrating global climate, El Niño, undergoes long-term variations closely related to the secular solar activity variations. Both the intensity and occurrence frequency of El Niño are low at secular solar maximum and high at secular solar minimum. In the 11-year solar cycle, El Nino has a statistically significant minimum one year before solar activity maximum.

The influence of solar activity on El Niño is mediated by the atmospheric centers of action, which change their strength and position in response to longterm changes of solar activity. In the Northern Pacific Ocean, the pressure in both the Hawaiian High and the Aleutian Low drops, they move to higher latitudes, the Hawaiian High is displaced to the east, and the Aleutian Low to the west with increasing solar activity. In the Southern hemisphere, the pressure in the Indian Ocean High decreases, and in the Southern Pacific High increases with increasing solar activity. Conditions in secular solar maximum are more unfavorable for initiating El Niño. The mechanisms through which solar activity affects atmospheric circulation and baric systems are still a matter of controversy.

\section{Refererences}

1. Rasmusson, E.M., et al. // Science, 1983, 222, 1195-1202.

2. Quinn, W.H., at al. // J. Geophys. Res., 1987, 92, 14449-14461.

3. Ortlieb, L. / Cambridge Univ. Press, 2000, 207-295.

4. Deser, C., at al. // J. Geophys. Res., 1987, 92, 14189-14196.

5. Hoyt, D. Vat., at al. // Solar Phys., 1998, 179, 189-219. 